\title{
Plant Extracts Display Synergism with Different Classes of Antibiotics
}

\author{
DANIELLE M. SILVA ${ }^{1}$, PRISCILLA A. DA COSTA ${ }^{1}$, ANDRÉA O.B. RIBON ${ }^{1}$, GISLAINE \\ A. PURGATO ${ }^{1}$, GASPAR DIAZ-MUÑOZ ${ }^{2}$ and MARISA A.N. DIAZ ${ }^{1}$ \\ ${ }^{1}$ Departamento de Bioquímica e Biologia Molecular, Centro de Ciências Biológicas e da Saúde, Universidade \\ Federal de Viçosa, Avenida Peter Henry Rolfs, s/n, Campus Universitário, 36570-900 Viçosa, MG, Brazil \\ ${ }^{2}$ Departamento de Química, Instituto de Ciências Exatas/ICEX, Universidade Federal de Minas Gerais, \\ Avenida Presidente Antônio Carlos, 6627, Pampulha, 31270-901 Belo Horizonte, MG, Brazil
}

Manuscript received on February 8, 2018; accepted for publication on April 25, 2018

\begin{abstract}
How to cite: SILVA DM, COSTA PA, RIBON AOB, PURGATO GA, DIAZ G AND DIAZ MAN. 2019. Plant Extracts Display Synergism with Different Classes of Antibiotics. An Acad Bras Cienc 91: e20180117. DOI 10.1590/00013765201920180117.
\end{abstract}

\begin{abstract}
One manner in which plant-derived compounds exert their antibiotic potential is the synergism, a positive interaction between two compounds. Studies indicate that the use of plant extracts combined with antimicrobials may promote a significant reduction of the minimum inhibitory concentrations of antibiotics for bacterial strains. This study aimed to evaluate the activity of plant extracts and antibiotics as well as their combination on Staphylococcus aureus. The activity of 15 plant extracts was evaluated using diffusion assay. The minimum inhibitory concentrations (MICs) and the interactions between the extracts and antibiotics as well as compound emodin were evaluated with the checkerboard method. The active extracts were a hexane extract of the leaves of Baccharis dracunculifolia and the ethanol extracts of the leaves of Plectranthus ornatus, Inga edulis, Salvia officinalis and Senna macranthera. The Plectranthus ornatus extract displayed synergism with ampicillin (a $\beta$-lactam), kanamycin and gentamicin (aminoglycosides), with 8-fold reductions in the MIC. The same reduction was observed for the extracts of Salvia officinalis and Senna macranthera, which displayed the lowest MIC. Using these combinations resulted in a reduction in the minimum dose required for effective antimicrobial effects, which is interesting because it may decrease both the risk of side effects and the costs of treatment.
\end{abstract}

Key words: antibiotics, bovine mastitis, plant extract, Staphylococcus aureus.

\section{INTRODUCTION}

The increase in bacterial resistance to currently known drugs is an issue of global concern and reinforces the need for new classes of antibacterial substances. Compounds of natural origin are potential sources of new chemical scaffolds for antibiotic development (Ortholand and Ganesan

Correspondence to: Marisa Alves Nogueira Diaz

E-mail: marisanogueira@ufv.br

ORCid: https://orcid.org/0000-0002-3370-4149
2004) but unlike synthetic drugs, they are not associated with side effects, are cheaper, come from renewable sources and have greater acceptance due to a long history of use (Chanda and Rakholiya 2011). One manner in which plant-derived compounds exert their potential as antibiotics is synergism, a positive interaction created when two agents are combined (González-Lamothe et al. 2011) that results in an inhibitory effect greater than the sum of their individual effects (Chanda and 
Rakholiya 2011). Many currently used drugs are based on synergistic interactions between different antibiotics with different targets (Sibanda and Okoh 2007). Studies indicate that the use of plant extracts combined with antimicrobials promotes a significant reduction of the minimum inhibitory concentrations of antibiotics for bacterial strains (Darwish et al. 2002, Betoni et al. 2006, Souza et al. 2011). Darwish et al. (2002) observed that the efficacy of the antibiotics gentamicin and chloramphenicol was increased against isolates of Staphylococcus aureus when the drugs were combined with extracts produced from Jordanian plants. Betoni et al. (2006) also observed synergistic interactions between eight Brazilian herbal extracts with antibiotics against $S$. aureus isolated from human infections. Sousa et al. (2011) reported the antibacterial activity and the positive interference of extracts from the leaves and roots of Lantana camara and Lantana lantana on the activity of aminoglycosides against Gram-positive and Gramnegative strains.

Previous studies conducted by our group demonstrated that various extracts of plants were effective in inhibiting the growth of bovine-origin S. aureus (Diaz et al. 2010, Rossi et al. 2011). This study aimed to evaluate the activity of plant extracts and antibiotics as well as their combination on $S$. aureus isolates from animals affected with bovine mastitis.

\section{MATERIALS AND METHODS}

\section{PLANT MATERIAL}

Plectranthus ornatus (voucher 39644), Solanum cernuum (voucher 011654), Calendula officinalis (voucher 15593), Cymbopogon citrates (voucher 30283), Symphytum officinale (voucher 24060), Inga edulis (voucher 2173), Jacaranda cuspidifolia (voucher 21419), Azadirachta indica, Salvia officinalis (voucher 1240), Bixa Orellana (voucher 31977), Baccharis dracunculifolia (voucher
31322), Ocimum basilicum, Senna macranthera (voucher 1237), Helianthus annuus (voucher 7650) and Acrocomia aculeata specimens were collected in Viçosa, Minas Gerais, Brazil. A voucher of each specimen used was deposited at the herbarium of the Department of Botany of the Universidade Federal de Viçosa. The specimens (Azadirachta indica, Ocimum basilicum and Acrocomia aculeate) that do not have voucher are still up identification. The plant parts were dried at $40{ }^{\circ} \mathrm{C}$ for $24 \mathrm{~h}$ in an air circulation oven before the extracts were prepared.

\section{EXTRACT PREPARATION}

The leaves ( $500 \mathrm{~g})$ of P. ornatus, Solanum cernuum, C. officinalis, C. citrates, S. officinale, I. edulis, J. cuspidifolia, A. indica, S. officinalis, B. orellana and O. basilicum (500 g) were extracted with ethanol (2 L) and the roots of $S$. macranthera (500 g) with dichloromethane for $120 \mathrm{~h}$ at room temperature. The solvent was removed under vacuum at $40{ }^{\circ} \mathrm{C}$ to obtain an ethanolic extract of each plant. The leaves of $B$. dracunculifolia, $A$. aculeate and seeds of $H$. anus were extracted with hexane by the same procedure. All extracts were stored at $4{ }^{\circ} \mathrm{C}$.

\section{BACTERIAL STRAINS}

S. aureus 3993 and 4125 strains, (identified by the Embrapa Dairy Cattle from the Milk Microbiology Laboratory) as an infectious reference microorganism which were isolated from animals with mastitis infections, were kindly provided by Embrapa/CNPGL, Juiz de Fora, MG, Brazil. The bacterial cultures were streaked on plates containing brain heart infusion agar (BHA; Himedia ${ }^{\circledR}$ ) and incubated for $16 \mathrm{~h}$ at $37{ }^{\circ} \mathrm{C}$. Müeller Hinton broth (Himedia ${ }^{\circledR}$ ) was used for testing antibacterial activities. The cell concentration was adjusted to

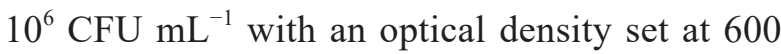
$\mathrm{nm}$. Stock cultures were maintained in BHI agar containing $25 \%$ glycerol at $-80{ }^{\circ} \mathrm{C}$. 


\section{ANTIMICROBIAL ACTIVITY}

Antimicrobial activity was assessed using the agar diffusion assay. For this purpose, $100 \mu \mathrm{L}$ of a suspension containing $10^{6} \mathrm{CFU} \cdot \mathrm{mL}^{-1}$ was spread in Petri dishes containing Müeller Hinton agar (Himedia ${ }^{\circledR}$ ). Holes of approximately $5 \mathrm{~mm}$ in diameter and $3 \mathrm{~mm}$ in height were created in the agar and were filled with $30 \mu \mathrm{L}$ of the extracts at a concentration of $50 \mathrm{mg} \cdot \mathrm{mL}^{-1}$. The controls were prepared with $30 \mu \mathrm{L}$ of DMSO and $5 \mathrm{mg} \cdot \mathrm{mL}^{-1}$ of ampicillin (Sigma $\left.{ }^{\circledR}, A 9518\right)$. The plates were incubated for $24 \mathrm{~h}$ at $37^{\circ} \mathrm{C}$, and the subsequent inhibition zones were measured in $\mathrm{mm}$. Inhibition zones greater than $7 \mathrm{~mm}$ were considered positive (Nascimento et al. 2000). Student's t-test $(p<0.05)$ was performed to compare the results of the inhibition zones obtained from the extracts with the positive control. Tests were performed twice in triplicate.

\section{MINIMAL INHIBITORY CONCENTRATION (MIC)} ASSAY

The activity of the extracts on bacterial growth was determined using the microdilution method described in CLSI (2003). The microorganisms were initially grown on BHI agar plates (Himedia ${ }^{\circledR}$ ) and pre-incubated for $24 \mathrm{~h}$ at $37{ }^{\circ} \mathrm{C}$. Isolated colonies were then inoculated into Müeller-Hinton broth (Himedia ${ }^{\circledR}$ ) and incubated at $37{ }^{\circ} \mathrm{C}$ with shaking at $180 \mathrm{rpm}$ until the exponential phase was reached. The culture was subsequently diluted to an optical density corresponding to the standard 0.5 on the McFarland scale $\left(\mathrm{OD}_{620}=0.10\right)$. Microplate wells were filled with $100 \mu \mathrm{L}$ of Müeller-Hinton broth that had extracts concentrations ranging from $0.1 \mathrm{mg} \cdot \mathrm{mL}^{-1}$ to $10 \mathrm{mg} \cdot \mathrm{mL}^{-1}$ and $10^{6} \mathrm{CFU} \cdot \mathrm{mL}^{-1}$ of bacterial suspensions. Whereas the DMSO could be bactericidal a control of microbial growth in this solvent was done with $100 \mu \mathrm{L}$ of bacterial suspension and $100 \mu \mathrm{L}$ of Müeller-Hinton broth with DMSO at the highest concentration used in the preparation of the extract. After $24 \mathrm{~h}$ at 37 ${ }^{\circ} \mathrm{C}, 4 \mu \mathrm{L}$ of $p$-iodonitrotetrazolium (INT, I8377, Sigma $\left.{ }^{\circledR}\right)$ was added to each well, and the plate was incubated for an additional $2 \mathrm{~h}$ at $37^{\circ} \mathrm{C}$. A change in the color of the medium from yellow to pink-violet was used as an indication of bacterial growth. The minimal inhibitory concentration of the antibiotics was determined by the same procedure, with concentrations ranging from $0.1 \mathrm{mg} \cdot \mathrm{mL}^{-1}$ a 500 $\mathrm{mg} \cdot \mathrm{mL}^{-1}$.

\section{EVALUATION OF THE INTERACTIONS BETWEEN PLANT EXTRACTS AND ANTIBIOTICS}

The checkerboard method, which is commonly used for measurement of interactive inhibition, was used to determine the interactions between the antibiotics and the natural antimicrobials (Palaniappan and Holey 2010). Synergistic interactions involving the plant extracts (drug A) plus the antibiotics (drug B) were tested. The concentrations of the agents used started from twice their MIC value and were serially diluted in five-fold steps. The effects of combinations were evaluated by calculating the FIC (Fractional Inhibitory Concentration) index for each combination using the formulas displayed below:

FIC of drug $\mathrm{A}\left(\mathrm{FIC}_{\mathrm{A}}\right)=\mathrm{MIC}$ of compound $\mathrm{A}$ in combination/MIC of compound $\mathrm{A}$ alone

FIC of drug B $\left(\right.$ FIC $\left._{\mathrm{B}}\right)=$ MIC of compound Bin combination/MIC of compound $\mathrm{B}$ alone

$$
\mathrm{FIC} \text { index }=\mathrm{FIC}_{\mathrm{A}}+\mathrm{FIC}_{\mathrm{B}}
$$

Synergy was defined as an FIC index $\leq 0.5$. An FIC $\geq 4.0$ indicated antagonism between the two agents, between 4.0 and 1.0 indicated indifference, and between 1.0 and 0.5 was evaluated as an additive interaction.

\section{RESULTS}

This study evaluated the antimicrobial potential of plant extracts from Viçosa, Minas Gerais, 
Brazil. The activity of these extracts was tested on strains of $S$. aureus isolated from cows affected with mastitis. Five of the 15 plant extracts tested displayed antimicrobial activity, as indicated by inhibition zones greater than $7 \mathrm{~mm}$ (Table I). The active extracts were the hexane extract of the leaves of $B$. dracunculifolia and the ethanol extracts of the leaves of P. ornatus, I. edulis, S. officinalis and $S$. macranthera.

The MICs for the active extracts were determined (Table II). Among the plant extracts tested, S. macranthera displayed the lowest MIC (0.2 mg. $\left.\mathrm{mL}^{-1}\right)$, followed by $S$. officinalis $\left(0.3 \mathrm{mg} \cdot \mathrm{mL}^{-1}\right)$. The highest MICs were observed for the extracts of P. ornatus $\left(2.0 \mathrm{mg} \cdot \mathrm{mL}^{-1}\right) B$. dracunculifolia $\left(5.0 \mathrm{mg} \cdot \mathrm{mL}^{-1}\right)$ and I. edulis $(7.0$ $\left.\mathrm{mg} \cdot \mathrm{mL}^{-1}\right)$.

In addition to the antimicrobial potential of plant extracts, in this study, we investigated the combined effect of the active extracts with antibiotics traditionally used to treat bovine mastitis. First, the MICs of five antibiotics, namely ampicillin, kanamycin, chloramphenicol, gentamicin, and tetracycline were determined (Table III). The checkerboard method was used to determine the interactions between the antibiotics and the active extracts. The concentrations of the extracts and antibiotics varied between 1/8 MIC to $2 \mathrm{MIC}$ when combined. Based on the lower combined concentrations where bacterial growth inhibition was observed, the fractional inhibitory concentration index (FIC) was calculated and the type of interaction was determined (Table IV).

In almost all combinations of extracts and antibiotics tested, additive or synergistic interactions were observed. Only the interaction between $S$. officinalis and chloramphenicol was indifferent. No antagonistic interactions were detected.

The $P$. ornatus extract displayed synergism with ampicillin ( $\beta$-lactam), kanamycin and gentamicin (aminoglycosides), with 8-fold reductions in the MIC. The same reduction was observed for $S$. officinalis extract, which demonstrated synergism with ampicillin, kanamycin, gentamicin and tetracycline but displayed an indifferent interaction with chloramphenicol. The same results observed for the $S$. officinalis extract were observed for the $S$. macranthera extract, except for the interaction between chloramphenicol and $S$. macranthera extract, which was additive.

\section{DISCUSSION}

S. aureus is an important human pathogen and also a relevant pathogen that causes diseases in animals.

TABLE I

Staphylococcus aureus inhibition zones of the active extracts ( $\mathrm{mm})$.

\begin{tabular}{ccccc}
\hline \multirow{2}{*}{ Extracts } & \multicolumn{2}{c}{ S. aureus 4125} & \multicolumn{2}{c}{ S. aureus 3993 } \\
\cline { 2 - 5 } & Inhibition zones \pm SD & $\begin{array}{c}p \text { value } \\
\text { t-test }(0.05)\end{array}$ & $\begin{array}{c}\text { Inhibition zones } \pm \text { SD } \\
\text { t-test }(0.05)\end{array}$ & 0.01 \\
\hline $\begin{array}{c}\text { Baccharis } \\
\text { racunculifolia }\end{array}$ & $10.16 \pm 0.71$ & 0.001 & $9.83 \pm 0.24$ & 0.001 \\
Inga edulis & $14.00 \pm 0.94$ & 0.001 & $16.66 \pm 1.41$ & 0.003 \\
Plectranthus ornatus & $12.49 \pm 1.65$ & 0.005 & $9.16 \pm 0.71$ & 0.012 \\
Salvia officinalis & $21.83 \pm 2.59$ & 0.001 & $20.33 \pm 0.47$ & 0.027 \\
Senna macranthera & $15.49 \pm 0.23$ & 0.005 & $12.66 \pm 0.47$ & $\mathrm{nd}$ \\
DMSO & $0.00 \pm \mathrm{nd}$ & $\mathrm{nd}$ & $0.00 \pm \mathrm{nd}$ & 0.003 \\
Ampicillin & $24.25 \pm 0.35$ & 0.005 & $24.10 \pm 0.28$ & \\
\hline
\end{tabular}

Nd: Not determined. 
TABLE II

Values of minimum inhibitory concentrations (mg. $\mathrm{mL}^{-1}$ ) obtained for the active plant extracts.

\begin{tabular}{ccc}
\hline \multirow{2}{*}{ Extracts } & \multicolumn{2}{c}{$\begin{array}{c}\text { Minimum inhibitory concentration } \\
(\mathrm{MIC})\left(\mathrm{mg} \cdot \mathrm{mL}^{-1}\right)\end{array}$} \\
\cline { 2 - 3 } & S. aureus 3993 & S. aureus 4125 \\
\hline $\begin{array}{c}\text { Baccharis } \\
\text { dracunculifolia } \\
\text { Plectranthus } \\
\text { ornatus }\end{array}$ & 5 & 5 \\
Salvia officinalis & 1.2 & 1.2 \\
Inga edulis & 0.3 & 0.3 \\
Senna & 7 & 7 \\
macranthera & 0.2 & 0.2 \\
\hline
\end{tabular}

TABLE III

Values of minimum inhibitory concentrations (mg. $\left.\mathrm{mL}^{-1}\right)$ obtained for the tested antibiotics.

\begin{tabular}{ccc}
\hline \multirow{2}{*}{ Antibiotic } & \multicolumn{2}{c}{$\begin{array}{c}\text { Minimum inhibitory concentration } \\
(\mathrm{MIC})\left(\mathrm{mg} \cdot \mathrm{mL}^{-1}\right)\end{array}$} \\
\cline { 2 - 3 } & S. aureus 3993 & S. aureus 4125 \\
\hline Ampicillin & 0.3 & 7 \\
Kanamycin & 2 & 2 \\
Chloramphenicol & 8 & 8 \\
Gentamicin & 0.8 & 0.6 \\
Tetracycline & 0.3 & 0.25 \\
\hline
\end{tabular}

In dairy cattle this bacteria causes mastitis, an inflammation of the udder that causes significant economic losses worldwide. Antibiotic therapy is commonly used by veterinarians to treat infection increasing the chance of antimicrobial resistance over the years (Oliver and Murinda 2012). Saini et al. (2012) showed that intramammary administration of a penicillin-novobicin combination used in the treatment of mastitis was associated with increased antimicrobial resistance, in particular to ampicillin. Other studies conducted in different countries showed that resistance of bovine $S$. aureus strains can range between $5.2 \%$ and $77.3 \%$ for ampicillin (Oliveira et al. 2012, Li et al. 2009) between 0\% and $44.2 \%$ for gentamicin (Persson et al. 2011, Jumarnović et al. 2011) and between 3\% and $60 \%$ for tetracycline ( $\mathrm{Li}$ et al. 2009, Jumarnović et al. 2011). In this sense, new methods to reduce the development of resistance to antibiotics are urgently needed.

A large variety of molecules with potential antimicrobial activity are produced from plant secondary metabolism. It should be highlighted that most of these molecules have a weak antibiotic activity when compared to antibiotics produced by bacteria or fungi (Hemaiswarya et al. 2008). However, these compounds can act in synergism with antimicrobials to potentiate their effect and help the host to overcome the infection.

This study evaluated the antimicrobial potential of fifteen plant species on bovine-origin S. aureus. Although the antimicrobial activity of most of the species tested here has been already described for other bacterial species (Parente et al. 2009, Sharma et al. 2009, Vargas et al. 2010) this is the first time their activity was assayed against $S$. aureus.

Extracts of $B$. dracunculifolia, P. ornatus, $I$. edulis, S. officinalis, and S. macranthera displayed biological activity. S. officinalis extract displayed the largest inhibition zones (Figure 1). The antimicrobial potential of the plant extracts of $S$. officinalis on Gram-positive bacteria other than $S$. aureus and Gram-negative bacteria has been previously reported (Bara and Vanetti 1998, Haida et al. 2007).

There is no consensus on the acceptable level of inhibition when comparing natural products with antibiotic standards. Some authors consider natural products only effective when they have levels of inhibition similar to antibiotics. Others, however, accept compounds as efficacious with levels of inhibition lower than the normal levels observed with commercial antimicrobials (Duarte 2006). A plant material classification based on MIC results was proposed by Aligiannis et al. (2001) where extracts with strong inhibition have an MIC of 0.5 mg.mL ${ }^{-1}$; moderate inhibition, between 0.6 to 1.5 $\mathrm{mg} \cdot \mathrm{mL}^{-1}$; and weak inhibition, above $1.6 \mathrm{mg} \cdot \mathrm{mL}^{-1}$. Using these criteria, the extracts of $S$. officinalis (MIC of $0.3 \mathrm{mg} \cdot \mathrm{mL}^{-1}$ ) and S. macranthera (MIC of 
TABLE IV

Interaction between plant extracts and antibiotics on Staphylococcus aureus strains.

\begin{tabular}{|c|c|c|c|c|c|c|c|c|c|}
\hline \multirow{2}{*}{ Extract } & \multirow{2}{*}{ Antibiotic } & \multicolumn{4}{|c|}{ S. aureus 3993} & \multicolumn{4}{|c|}{ S. aureus 4125} \\
\hline & & FIC ant & FIC ext & $\sum \mathrm{FIC}$ & Interaction & FIC ant & FIC ext & $\sum \mathrm{FIC}$ & Interaction \\
\hline \multirow[t]{5}{*}{1} & Ampicillin & 1/8 MIC & 1/8 MIC & 0.25 & Synergism & $1 / 8 \mathrm{MIC}$ & 1/4 MIC & 0.375 & Synergism \\
\hline & Kanamycin & 1/8 MIC & 1/8 MIC & 0.25 & Synergism & 1/8 MIC & 1/8 MIC & 0.25 & Synergism \\
\hline & Chlo & $1 \mathrm{MIC}$ & 1/8 MIC & 0.75 & Additive & $1 \mathrm{MIC}$ & 1/8 MIC & 0.75 & Additive \\
\hline & Gentamicin & 1/8 MIC & 1/4 MIC & 0.375 & Synergism & 1/8 MIC & 1/8 MIC & 0.25 & Synergism \\
\hline & Tetracycline & 1/2 MIC & 1/4 MIC & 0.75 & Additive & $1 \mathrm{MIC}$ & 1/8 MIC & 0.875 & Additive \\
\hline \multirow[t]{5}{*}{2} & Ampicillin & 1/8 MIC & 1/8 MIC & 0.25 & Synergism & $1 / 2 \mathrm{MIC}$ & 1/8 MIC & 0.625 & Additive \\
\hline & Kanamycin & 1/8 MIC & 1/4 MIC & 0.375 & Synergism & 1/8 MIC & 1/4 MIC & 0.375 & Synergism \\
\hline & Chlo & 1/2 MIC & $1 \mathrm{MIC}$ & 1.5 & Indifferent & $1 / 2 \mathrm{MIC}$ & $1 \mathrm{MIC}$ & 1.5 & Indifferent \\
\hline & Gentamicin & 1/8 MIC & 1/8 MIC & 0.25 & Synergism & 1/4 MIC & 1/8 MIC & 0.375 & Synergism \\
\hline & Tetracycline & 1/4 MIC & 1/8 MIC & 0.375 & Synergism & 1/4 MIC & 1/8 MIC & 0.375 & Synergism \\
\hline \multirow[t]{5}{*}{3} & Ampicillin & 1/2 MIC & 1/8 MIC & 0.5 & Synergism & 1/4 MIC & 1/8 MIC & 0.375 & Synergism \\
\hline & Kanamycin & 1/8 MIC & 1/4 MIC & 0.375 & Synergism & 1/8 MIC & 1/4 MIC & 0.375 & Synergism \\
\hline & Chlo & $1 / 2 \mathrm{MIC}$ & 1/8 MIC & 0.625 & Additive & $1 / 2 \mathrm{MIC}$ & 1/4 MIC & 0.75 & Additive \\
\hline & Gentamicin & 1/4 MIC & 1/8 MIC & 0.325 & Synergism & 1/4 MIC & 1/8 MIC & 0.325 & Synergism \\
\hline & Tetracycline & 1/4 MIC & $1 / 8 \mathrm{MIC}$ & 0.325 & Synergism & 1/4 MIC & 1/8 MIC & 0.325 & Synergism \\
\hline
\end{tabular}

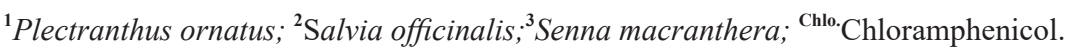

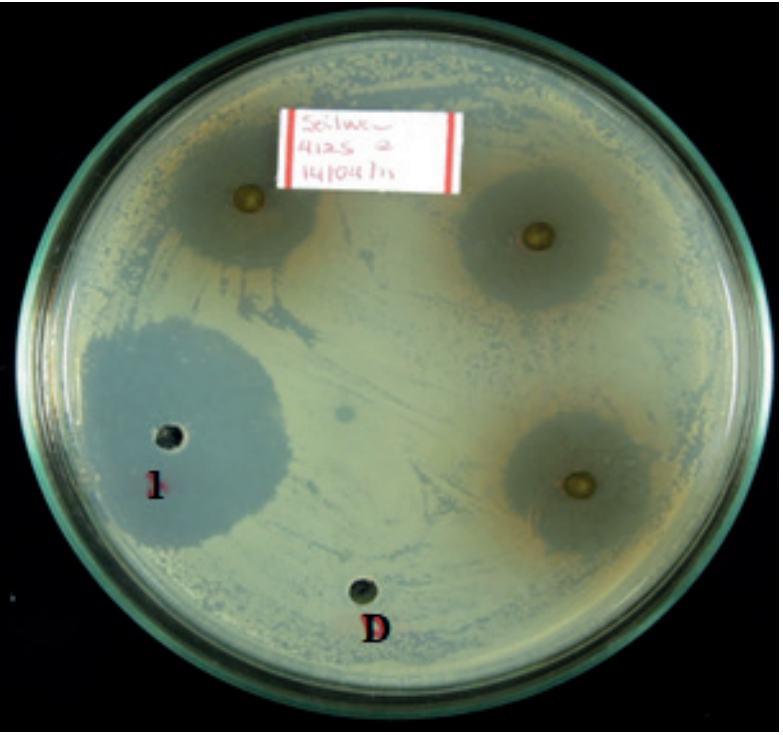

Figure 1 - Inhibition zones of sage (S. officinalis) extract on $\mathrm{S}$. aureus 4125 . The positive control of growth inhibition antibiotic ampicillin was identified in the figure by number 1 . The negative control of inhibition was done with DMSO (D).

$0.2 \mathrm{mg} \cdot \mathrm{mL}^{-1}$ ) can be considered to have displayed strong inhibition. In contrast, extracts of $P$. ornatus (MIC of $1.2 \mathrm{mg} \cdot \mathrm{mL}^{-1}$ ) can be considered to have displayed moderate inhibition, $B$. dracunculifolia and I. edulis, with an MIC of $5.0 \mathrm{mg} . \mathrm{mL}^{-1}$ and 7.0 $\mathrm{mg} . \mathrm{mL}^{-1}$, respectively, are classified as displaying weak inhibition.

Based on the checkerboard assay, synergism was observed between the P. ornatus extract and ampicillin, kanamycin or gentamycin, with an 8-foldreductionin the MIC. The extract of $S$. officinalis also displayed synergism with ampicillin, kanamycin, gentamicin, and tetracycline, though the extract displayed an indifferent interaction with chloramphenicol. An 8-fold decrease in the MIC value was also detected. The same reduction was observed for the extract of $S$. macranthera; however, its interaction with chloramphenicol was considered additive.

The main components of $S$. officinalis and $P$. ornatus extracts are the essential oils caryophyllene, eugenol, and thymol, although lower concentrations of rosmarinic acid, caffeic acid, carnosol, and flavonoids are also found in the former (Velickovic 
et al. 2003, De Albuquerque et al. 2007). S. macranthera is rich in phenolic compounds as emodin, physcione and chrysophanol and have been used by some farmers to treat bovine mastitis, a chronic infection that produces an inflammatory response in cow's udders and that is caused by $S$. aureus (Andrade 2015), suggesting that compounds present in this extract could be responsible for the decrease observed in MIC combined with $\beta$ lactams antibiotic.

No specificity to a group of antibiotics was observed which suggests that the crude extract of these plants might contain a mixture of compounds that potentiate the activities of different antibiotics. These compounds facilitate a reduction in the minimum dose required for effective antimicrobial activity. This is interesting because smaller doses can reduce the chance of side effects as well as reduce the costs of treatment. However, for the purposes of therapeutic use, the mode of action of plant extracts should be explored to gain a comprehensive view of the molecular mechanisms involved in their interactions.

\section{CONCLUSIONS}

Synergism against the two strains of $S$. aureus was observed between the extracts of P. ornatus, $S$. officinalis and $S$. macranthera and different antibiotics used in the treatment of bovine mastitis. The interactions displayed between the extracts of $S$. officinalis and S. macranthera and chloramphenicol were additive and between the extract of $P$. ornatus and chloramphenicol was indifferent. The present results are promising and may enhance the use of natural products instead of antibiotics or these can be used in association with active extracts to reduce the use of existing antibacterial drugs. Using these combinations can result in a reduction in the minimum dose required for effective antimicrobial effects, which is interesting because it may decrease both the risk of side effects and the costs of treatment of infectious diseases.

\section{ACKNOWLEDGMENTS}

Bacterial isolates were kindly provided by the Empresa Brasileira de Pesquisa Agropecuária (EMBRAPA) Dairy Cattle, Juiz de Fora, Minas Gerais. The scholarship of DMS was provided by the Fundação de Amparo à Pesquisa do Estado de Minas Gerais (FAPEMIG).

\section{AUTHOR CONTRIBUTIONS}

Danielle Mendes Silva, Priscilla Almeida da Costa and Gislaine Aparecida Purgato: wrote the article; Andréa de Oliveira Barros Ribon and Gaspar DiazMuñoz: statistical analyzes; Marisa Alves Nogueira Diaz: statistical analysis and final supervision of the text.

\section{REFERENCES}

ALIGIANNIS N, KALPOUTZAKIS E, MITAKU S AND CHINOU IB. 2001. Composition and antimicrobial activity of the essential oils of two Origanum species. J Agric Food Chem 49: 4168-4170.

ANDRADE FI, PURGATO GA, MAIA TF, SIQUEIRA RP, LIMA S, DIAZ G AND DIAZ MAN. 2015. Chemical Constituents and an Alternative Medicinal Veterinary Herbal Soap Made from Senna macranthera. Evid-Based Complementary Altern Med 2015: 6.

BARA MTF AND VANETTI MCD. 1998. Estudo da atividade antibacteriana de plantas medicinais, aromáticas e corantes naturais. Braz J Pharmacog 7: 22-34.

BETONI JEC, MANTOVANI RP, BARBOSA LN, DI STASI LC AND FERNANDES JUNIOR A. 2006. Synergism between plant extract and antimicrobial drugs used on Staphylococcus aureus diseases. Mem Inst Oswaldo Cruz 101: 387-390.

CHANDA S AND RAKHOLIYA K. 2011. Combination therapy: Synergism between natural plant extracts and antibiotics against infectious diseases. In: Mendez-Vilas A (Ed), Science against microbial pathogens: communicating current research and technological advances. Badajos/ Spain: Formatex, p. 520-529.

CLSI - CLINICAL \& LABORATORY STANDARDS INSTITUTE. 2003. Methods for Dilution Antimicrobial Susceptibility Tests for Bacteria That Grow Aerobically, 
Approved Standard, $6^{\text {th }}$ ed., NCCLS document M7-A6 (ISBN 1-56238-486-4). NCCLS, 940 West Valley Road, Suite 1400, Wayne, Pennsylvania 19087-1898, USA.

DARWISH RM, ABURJAI T, AL-KHALIL S AND MAHAFZAH A. 2002. Screening of antibiotic resistant inhibitors from local plant materials against two different strains of Staphylococcus aureus. J Ethnopharmacol 79: 359-364.

DE ALBUQUERQUE RL, SILVA MGV, MACHADO MIL, MATOS FJA, DE MORAIS SM AND NETO JS. 2007. Chemical composition and antioxidant activity of Plectranthus grandis and P. ornatus essential oils from north-eastern Brazil. Flavour Fragr J 22: 24-26.

DIAZ MAN, ROSSI CC, MENDONÇA VR, SILVA DM, RIBON AOB, AGUILAR AP AND MUÑOZ GD. 2010. Screening of medicinal plants for antibacterial activities on Staphylococcus aureus strains isolated from bovine mastitis. Braz J Pharmacog 20: 724-728.

DUARTE MCT. 2006. Atividade antimicrobiana de plantas medicinais e aromáticas utilizadas no Brasil. Rev Multiciência 7: 1-17.

GONZÁLEZ-LAMOTHE R, MITCHELL G, GATTUSO M, DIARRA MS, MALOUIN F AND BOUARAB K. 2009. Plant antimicrobial agents and their effects on plant and human pathogens. Int J Mol Sci 10: 3400-3419.

HAIDA KS, PARZIANELLO L, WERNER S, GARCIA DR AND INÁCIO CV. 2007. Avaliação in vitro da atividade antimicrobiana de oito espécies de plantas medicinais. Arq Ciências Saúde UNIPAR 11: 185-192.

HEMAISWARYA S, KRUTHIVENTI AK AND DOBLE M. 2008. Synergism between natural products and antibiotics against infectious diseases. Phytomedicine 15: 639-652.

JUMARNOVIĆ J, BAČANEK B, PAVLJAK I, SUKALIĆ T, JAKI V, MAJNARIĆ D AND SOKOLOVIĆ J. 2011. Susceptibility of Staphylococcus aureus strains isolated from bovine intramammary infections. Med Sci 511: 105111.

LI JP, ZHOU HJ, YUAN L, HE T AND HU SH. 2009. Prevalence, genetic diversity, and antimicrobial susceptibility profiles of Staphylococcus aureus isolated from bovine mastitis in Zhejiang Province, China. [J Zhejiang Univ Sci B 10: 753-760.

NASCIMENTO GG, LOCATELLI J, FREITAS PC AND SILVA GL. 2000. Antibacterial activity of plant extracts and phytochemicals on antibiotic-resistant bacteria. Braz $\mathrm{J}$ Microbiol 31: 247-256.

OLIVEIRA L, LANGONI H, HULLAND C AND RUEGG PL. 2012. Minimum inhibitory concentrations of Staphylococcus aureus recovered from clinical and subclinical cases of bovine mastitis. J Dairy Sci 95: 19131920.
OLIVER SP AND MURINDA SE. 2012. Antimicrobial resistance of mastitis pathogens. Vet Clin North Am Food Anim Pract 28: 165-185.

ORTHOLAND JY AND GANESAN A. 2004. Natural products and combinatorial chemistry: back to the future. Curr Opin Chem Biol 8: 271-280.

PALANIAPPAN K AND HOLLEY RA. 2010. Use of natural antimicrobials to increase antibiotic susceptibility of drug resistant bacteria. Int J Food Microbiol 140: 164-168.

PARENTE LML, SILVA MSB, BRITO LAB, LINOJÚNIOR RS, PAULA JR, TREVENZOL LMF, ZATTA DT AND PAULO N. 2009. Efeito cicatrizante e atividade antibacteriana da Calendula officinalis L. cultivada no Brasil. Rev Bras Pl Med 11: 383-391.

PERSSON Y, NYMAN AKJ AND GRÖNLUNDANDERSSON U. 2011. Etiology and antimicrobial susceptibility of udder pathogens from cases of subclinical mastitis in dairy cows in Sweden. Acta Vet Scand 53: 36.

ROSSI CC, AGUILAR AP, DIAZ MAN AND RIBON AOB. 2011. Aquatic plants as potential sources of antimicrobial compounds active against bovine mastitis pathogens. Afr J Biotechnol 10: 8023-8030.

SAINI V, MCCLURE JT, SCHOLL DT, DEVRIES TJ AND BARKEMA HW. 2012. Herd-level association between antimicrobial use and antimicrobial resistance in bovine mastitis Staphylococcus aureus isolates on Canadian dairy farms. J Dairy Sci 95: 1921-1929.

SHARMA D, LAVANIA AA AND SHARMA A. 2009. In vitro comparative screening of antibacterial and antifungal activities of some common plants and weeds extracts. Asian J Exp Biol Sci 23: 169-172.

SIBANDA T AND OKOH AI. 2007. The challenges of overcoming antibiotic resistance: Plant extracts as potential sources of antimicrobial and resistance modifying agents. Afr J Biotechnol 6: 2886-2896.

SOUZA EO, BARRETO FS, RODRIGUES FFG AND DA COSTAJGM. 2011. Atividade antibacteriana e interferência de Lantana camara L. e Lantana montevidensis (Spreng.) Briq. na resistência de aminoglicosídeos. Rev Bras Biocienc 9: 1-5.

VARGAS FS, OLIVEIRA CF, GIRO EM, SACRAMENTO LV, SPOLIDORIO DM AND COSTA CAS. 2010. Efeito antimicrobiano e citotóxico do óleo essencial de Cymbopogon citratus sobre células odontoblastóides. ROBRAC 19: 101-108.

VELICKOVIC DT, RANDJELOVIC NV, RISTC MS, VELICKOVIC AS AND SIMELCEROVIC AA. 2003. Chemical constituents and antimicrobial activity of the ethanol extracts obtained from the flower, leaf and stem of Salvia Officinalis L. J Serb Chem Soc 68: 17-24. 